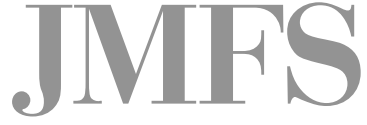

Journal of Management and Financial Sciences
Volume XI

Issue 33 (September 2018)

pp. $9-23$

Warsaw School of Economics

Collegium of Management and Finance

Przemysław Borkowski, Monika Bąk

Chair of Transport Economics

Faculty of Economics

University of Gdansk

\title{
Short and Long-Term Consequences of Further Regulation of the European Union Road Haulage Market
}

\begin{abstract}
The objective of this paper is to assess short and long-term consequences of the new regulatory framework in the European Union road haulage market as proposed by the European Commission in the "Mobility package". The initiative comprises a number of regulations aimed at technical and social aspects of the road haulage market. This study is based on qualitative research and takes into consideration different perspectives of expert knowledge. On the basis of their own methodological background (the evaluation framework and assessment criteria) the authors compare the expected impacts of the regulations on large and small transport enterprises. The assessment is based on a focused group study within Polish and Hungarian transport companies and several external experts' views (the list of the consulted experts is given in the acknowledgments section) and finalises with conclusions for different EU regions: the central and peripheral EU countries. The aim of this research is to show different aspects of the impact of the proposed measures on different types of transport businesses in Europe and to demonstrate diverse and sometimes opposite effects. The impacts are assessed against different enterprise types (small vs large transport companies) and a company's base of operation geographical location (core vs periphery). While the Commission states that the regulation is aimed primarily at equalizing companies' competitive chances, this study argues that the proposal may in fact lead to the more fragmented and less competitive internal road transport market.
\end{abstract}

Keywords: road haulage market, Mobility package, EU internal transport market, social regulations in transport

JEL Classification Codes: R40, O30 


\section{Introduction}

On 31 May 2017 the European Commission published the "Mobility package" comprising: Communication from the Commission, Europe on the Move, An agenda for a socially fair transition towards clean, competitive and connected mobility for all; new regulatory initiatives that should be adopted in the year following 31.05.2017 and which concern: charges for the use of transport infrastructure for interoperability of charging systems, access to the road freight haulage market and social regulations in road transport.

The basis for these changes are the challenges facing the transport sector in the EU countries and in today's competitive global market. The proposal is rooted in the heated discussion between various road sector actors in the EU. The proposal itself is only one of the scenarios which were widely commented at different transport fora. One has also to stress that the Commission proposal is one going very far towards further regulation of the EU road transport market, being in contradiction to the so far policy aimed at market liberalisation. The new regulation of the transport market as proposed by the European Commission under the joint name "Mobility package" focuses on the road freight transport. From all the transport sectors EU road haulage plays a key role in economic activities within the internal market. Road freight transport represents $75.8 \%$ of all the EU freight transport [Eurostat, 2018]. Road transport uses most extensively the developed infrastructure network. It is also one of the major employers in the EU with the number of employees exceeding 5 million [EC, 2015]. The main problem with the proposed measures is that their effect on road transport enterprises is not equal. The proposals will have mostly a negative impact on small companies and specifically on those based in more peripheral countries in the EU.

\section{New regulations on the European Union road haulage market}

The recent "Mobility package" was triggered by changes in the market share of hauliers from individual countries. It could be treated as a response to an increased share of hauliers from Central and Eastern Europe in the overall EU market who acquired a dominant position [Eurostat, 2018a]. It is also clearly a response to the introduction of unilateral restrictive measures by certain countries that were trying to protect their internal markets. Especially the German "Minimum Wage Act" (MiLoG) entered into force, according to which a worker must have received $€ 8.5$ per hour at a minimum ( $€ 8.84$ from 1.1.2017). Its potential impact on transport companies from peripheral countries like Poland is definitely negative [Patorska, Laurech, 2015]. Following Germany, similar regulations were introduced in the Netherlands, Austria, Italy and in France, where the application of minimum wages to foreign carriers under the Law on Development, Business and Equal Opportunities (the so-called loi Macron) forces 
companies to accept $€ 9.76$ per hour wage (the rate applicable as of 1.01.2017). The introduction of such national legislations must be considered a failure of the European Commission to effectively protect free market principles [Paprocki, 2015]. Those national regulations were protested by road transport companies from peripheral EU countries as going against basic free market principles and as such caused intervention of the European Commission. Nevertheless, it is obvious that with the size of German and French transport markets and their importance to the EU economy it was a move by national governments to install new, very strict regulations, which has prompted the European Commission to look for the EU level solution.

The "Mobility package" introduces, among others, key rules impacting competitiveness of transport enterprises. Especially of critical importance are the changes proposed in the following documents: Better access to the EU road haulage market - revision of the Regulations on Access to the Road Haulage Market and to the occupation of road transport undertaking (Regulations 1071/2009/EC and 1072/2009/EC 2009); Revision of the Directive 2006/1 on the Use of Hired Goods Vehicles; Enhancement of Social legislation in Road Transport - revision of Directive 2006/22/EC on the implementation of the social legislation + Lex specialis on posting of workers in road transport, including specific enforcement measures; Enhancement of Social legislation in Road Transport - revision of Regulation 2006/561/EC on driving and rest periods and of Regulation 2016/165/EU on tachographs. From the transport enterprises competitiveness and economic performance point of view, the crucial changes concern:

- cabotage; with the changes effectively reducing cabotage operations to 3 days;

- definition of the enterprise's domicile aimed at elimination of letterbox companies (companies which use one country's residence while operating from another country);

- working time and rest time of drivers; making them more elastic with allowance to extend their driving time in order to reach final destination or manage breaks during their rest time;

- a driver's regular weekly rest in the vehicle cabin; aimed at making resting outside the vehicle obligatory;

- applying regulations on posting workers to the road transport sector, aimed at the application of national wage in international transport.

The preliminary assessments show that the adoption of the Commission's proposal might negatively impact companies from peripheral EU countries, for instance more than $70 \%$ of companies based in Poland will be negatively affected [Bąk, Borkowski, Czuba, Koźlak, Zamojska, 2017]. The recent regulations are a big step back from the many years of the EU deregulation of road transport and are a reversal of the previous 30 years of increasingly liberal transport policy [Lafontaine, Valeri, 2009]. Also the overall impact of the increased regulation on the EU economic growth is negative, with high danger of an increase in the share of informal "gray market" in the EU road transport activities [Raczkowski, Schneider, Laroche, 2017]. The growth in the EU road transport happens regardless of the move to service-based economy which is less dependent on transport, and which occurred in the majority of the EU countries [Alises, Vassallo, 2016]. The decoupling of road transport from economic growth 
is only possible under the condition that road transport is competitive and efficient [Alises, Vassallo, Guzman, 2014]. It has already been proven that deregulation of road transport has a visible positive effect on competitiveness and reduction of transport prices [Ellison, 1985]. It may sometimes lead to abuse of competition through outsourcing to letterbox companies and other questionable practices [Hilal, 2008], it is nevertheless obvious that the rapid development of road haulage adds to the GDP growth [Lakshmanan, Anderson, 2002]. This phenomenon has also been the case of the EU [IRF, 2007]. On the macroeconomic level Krugman [1999] demonstrates that if transport costs are high, then external trade is relatively constrained and wages depend on the local level of competition for labour and jobs. However, if transport costs are lower, employers have access to a larger labour market and a wider range of skill levels, which can increase competition for employment.

Against this background it can be said that the newly proposed EU Commission's regulatory proposals are almost uniformly hailed as overregulation by companies from peripheral countries and as still overly liberal by representatives of the EU core countries [see for example: FTA, 2016]. Although the infringements in the existing EU road sector rules were rather frequent [Steer et al., 2013] they alone cannot be considered the reason for more regulation. It was the impact that hauliers from CEE countries had on the market dominating it and taking a significant share of domestic markets from companies based in the EU core countries and reaction of governments of those countries in a move toward protection of their own transport entities, which enticed the EU Commission to act. It is, therefore, interesting to look at possible impacts the "Mobility package" might have on both very distinctive groups.

\section{Assessing the impact of the road transport regulation on the performance of transport companies}

The impacts of the new regulations are difficult to assess in a quantitative form at this early stage of the proposal, partly due to the lack of exact and final definition of the discussed measures, but mostly because there is a certain lack of knowledge in regard to the administrative needs that will arise from those regulations and exact technical measures that will need to be applied by companies. Nevertheless, companies are able to position themselves against the proposal and evaluate a potential impact those new rules might have on their businesses in a qualitative way. This study is based on qualitative research and takes into consideration different perspectives of expert knowledge. On the basis of their own methodological background (the evaluation framework and assessment criteria) the authors compare the expected impacts of the regulations on large and small transport enterprises. The assessment is based on a focused group study within Polish and Hungarian transport companies (deep interviews with several companies) and several external experts' views (see the acknowledgment section).

Although most of them are unable to provide exact cost estimates for adherence to the new rules at the moment, they are able to indicate whether the change will have a significant 
or not significant impact and whether it is overall positive or negative. In order to assess the position of the transport sector within this research, the modified Likert scales are used for evaluation of potential impacts of the proposed new regulations ranging from -2 for strong negative impacts to +2 for strong positive impacts. In this method -1 score is associated with a limited negative impact, while +1 with a limited positive impact. Zero denotes no impact or an impact of very little influence on the researched field. The areas of company activities which were subjected to the evaluation against the Commission's proposal are summarised in table 1.

\section{Table 1. Road transport haulage companies areas of activities assessment criteria}

\begin{tabular}{|c|c|}
\hline Area & Assessment criteria \\
\hline $\begin{array}{l}\text { Change in the } \\
\text { number of performed } \\
\text { transport operations }\end{array}$ & $\begin{array}{l}\text { Number of transport cargo loads transported: }-2 \text { strong decline in the number of operations (considered } \\
\text { to be more than } 7 \%) ;-1 \text { decline in the number of operations (considered to be between } 2 \text { and } 7 \text { percent); } \\
0-\text { no change (changes within }+/-2 \% \text { boundary); } 1 \text { - increase in the number of operations (between } 2 \\
\text { and } 7 \text { percent), strong increase in the number of operations (by more than } 7 \% \text { ) }\end{array}$ \\
\hline Change in revenues & $\begin{array}{l}\text { Revenue level: }-2 \text { strong decline in revenues (by more than } 5 \% \text { ); }-1-\text { decline in revenues (reduction } \\
\text { between } 2 \% \text { and } 7 \%) ; 0-\text { no change (changes within }+/-2 \% \text { boundary); }+1-\text { increase in revenues } \\
\text { (between } 2 \% \text { and } 5 \%) ;+2 \text { strong increase in revenues (increase by more than } 5 \% \text { ) }\end{array}$ \\
\hline Availability of freights & $\begin{array}{l}\text { Change in demand for transport services: }-2 \text { strong negative (decrease by more than } 7 \% \text { ), }-1-\text { negative } \\
\text { (decrease between } 2 \% \text { and } 7 \% \text { ); } 0 \text { - no change (changes within }+/-2 \% \text { boundary); } 1 \text { - positive (increase } \\
\text { between } 2 \% \text { and } 7 \% \text { ); } 2 \text { - strong positive (increase by more than } 7 \% \text { ) }\end{array}$ \\
\hline Employment cost & $\begin{array}{l}\text { Change in wages and other compensation related costs: }-2-\text { strong negative (wage costs increase by } \\
\text { more than } 30 \%) ;-1-\text { negative (wage costs increase between } 5 \%-30 \%) ; 0-\text { no change (changes between } \\
+/-2 \%) ;+1-\text { positive (wage costs decrease between } 5 \%-30 \%) ;+2-\text { strong positive (wage costs } \\
\text { decrease by more than } 30 \%)\end{array}$ \\
\hline Other transport costs & $\begin{array}{l}\text { Change in costs other than wages: }-2-\text { strong negative (increase in other costs by more than } 10 \%) \\
-1-\text { negative (increase in other costs between } 3 \% \text { and } 10 \%) ; 0-\text { no change (changes within }+/ 13 \% \\
\text { boundary); }+1-\text { positive (decrease in other costs between } 3 \% \text { and } 10 \%) ;+2-\text { strong positive (decrease } \\
\text { in other costs of more than } 10 \% \text { ) }\end{array}$ \\
\hline $\begin{array}{l}\text { Price of transport } \\
\text { services }\end{array}$ & $\begin{array}{l}\text { Change in average price of transport services: }-2 \text { - strong negative (increase of more than } 5 \% \text { ); } \\
-1-\text { negative (increase between } 2 \% \text { and } 5 \% \text { ); } 0 \text { - no change (changes within }+/-2 \% \text { boundary); } \\
+1 \text { - positive (decrease between } 2 \% \text { and } 5 \%) ;+2-\text { strong positive (decrease of more than } 5 \% \text { ) }\end{array}$ \\
\hline $\begin{array}{l}\text { Fleet quantitative } \\
\text { change }\end{array}$ & $\begin{array}{l}\text { Change in the number of operational trucks: }-2-\text { strong negative (decrease by more than } 50 \% \text { for small } \\
\text { enterprises and more than } 10 \% \text { by large enterprises); }-1-\text { negative (decrease up to } 50 \% \text { for small } \\
\text { enterprises and between } 5 \% \text { and } 10 \% \text { for large enterprises); } 0 \text { - no change (no change for small enterprises } \\
\text { and changes ranging }+/ 15 \% \text { for large enterprises); }+1-\text { positive (increase up to } 50 \% \text { for small } \\
\text { enterprises and between } 5 \% \text { and } 10 \% \text { for large enterprises); }+2-\text { strong positive (increase by more than } \\
505 \text { for small enterprises and by more than } 10 \% \text { for large enterprises) }\end{array}$ \\
\hline Employment & $\begin{array}{l}\text { Change in the number of employees: }-2 \text { - strong negative (decrease in the number of employees by more } \\
\text { than } 25 \%) ;-1-\text { negative (decrease in the number of employees between } 5 \% \text { and } 25 \%) ; 0-\text { no change } \\
\text { (change within }+/-5 \% \text { boundary); }+1 \text { - positive (increase in the number of employees between } 5 \% \text { and } \\
25 \%) ;+2-\text { strong positive (increase in the number of employees by more than } 25 \% \text { ) }\end{array}$ \\
\hline $\begin{array}{l}\text { Value structure of } \\
\text { contracts }\end{array}$ & $\begin{array}{l}\text { Change in the structure of contracts: }-2 \text { - strong negative (significantly more low value and/or small } \\
\text { quantity cargo loads); }-1 \text { - negative (more low value and/or small quantity cargo loads); } 0 \text { - no change; }+1 \\
\text { - positive (more high value and/or large quantity cargo loads); +2 (significantly more high value and/or } \\
\text { large quantity cargo loads) }\end{array}$ \\
\hline $\begin{array}{l}\text { Number of empty } \\
\text { runs }\end{array}$ & $\begin{array}{l}\text { Change in the number of empty runs in relation to all runs: }-2-\text { strong negative (increase by over } \\
7 \% \text { ); }-1 \text { - negative (increase between } 2 \% \text { and } 7 \% \text { ); } 0 \text { - no change (change within }+/-2 \% \text { boundary; } \\
+1-\text { positive (decrease between } 2 \% \text { and } 7 \% \text { ); }+2-\text { strong positive (decrease by more than } 7 \% \text { ) }\end{array}$ \\
\hline Geographic direction & $\begin{array}{l}\text { Change in geographic distribution of transport operations: }-2 \text { - strong negative (concentration of operations } \\
\text { outside the EU); }-1 \text { - negative (shift of activities from all over the EU to concentration of operations } \\
\text { in neighbouring countries only); } 0-\text { no change; }+1 \text { positive - increased presence in the EU markets }\end{array}$ \\
\hline
\end{tabular}




\begin{tabular}{|l|l|}
\hline \multicolumn{1}{|c|}{ Area } & \multicolumn{1}{c|}{ Assessment criteria } \\
\hline Profit margin & $\begin{array}{l}\text { Profitability change: }-2-\text { strong negative (risk of operating below margin, loss in economic terms); } \\
-1-\text { negative (risk of operating at the margin, no profit); } 0-\text { no change (operating at a small margin, small } \\
\text { profit in economic terms); }+1-\text { positive (improved margins, more profitable than currently); }+2-\text { strong } \\
\text { positive (a significantly improved margin, high profits) }\end{array}$ \\
\hline
\end{tabular}

Source: the authors' own material.

The access to the representatives of transport companies from peripheral and core EU countries allows for measurement of companies' response to the Commission's proposal in regard to the companies located in core countries (mainly the EU-15) and those of peripheral EU countries. The division of countries into peripheral and core based on the distance from the geographical centre of the EU is given in table 2.

Table 2. Core and peripheral EU countries

\begin{tabular}{|l|l|}
\hline \multicolumn{1}{|c|}{ Core } & \multicolumn{1}{|c|}{ Peripheral } \\
\hline Austria (AT) & Bulgaria (BG) \\
Belgium (BE) & Estonia (EE) \\
The Czech Republic (CZ) & Finland (FI) \\
Denmark (DK) & Hungary (HU) \\
France (FR) & Ireland (IE) \\
Germany (DE) & Latvia (LV) \\
Italy (IT) & Lithuania (LT) \\
Luxembourg (LU) & Poland (PL) \\
Slovenia (SI) & Portugal (PT) \\
The Netherlands (NL) & Romania (RO) \\
& Slovakia (SK) \\
& Spain (ES) \\
& Sweden (SE) \\
& The United Kingdom (UK) \\
& Finland (FI) \\
\hline
\end{tabular}

Source: the authors' own material.

The other important dimension is a division into small transport companies (defined here as companies employing less than 10 people) and large transport companies. Small transport companies are characterised mostly by operating only in a selected few markets and deploying typically between 1-2 trucks. They are also usually family-run businesses and have limited access to external financing. They are very elastic operationally, but cannot absorb market shocks.

The results are based on focus group interviews within transport companies from two peripheral countries typical for this group (Poland and Hungary) conducted in Poland (in MayJune, 2018) and Hungary (May - June, 2017). Afterward, the consultation with representatives of core countries' transport industry were conducted during a hearing on the "Mobility package" in the European Parliament TRAN Committee (22.11.2017). 


\section{Expected effects of the "Mobility package" on the EU transport market}

The impacts of different regulations on EU commercial companies involved in haulage is different in the long and short run. Concentration of negative effects will take place during the first year or two years of the new regulations being in force. In the long run the most visible effect will be a reduction in the number of transport companies, with many small companies defaulting. The market will be much less competitive and negative effects from the companies' point of view will start to diminish. This is mainly because there will be few and mostly large companies left and thus, with the reduction of competition, they will be able to recover from most of the initial negative effects by dictating higher haulage prices. Moreover, the analysed effects will be much differentiated depending on the size of a transport company, its market of operation, current fleet composition and current level of costs vs profits. Analysis proves that the companies hit most by the new regulation will be smaller ones and predominantly from peripheral countries.

The new regulations' effects in regard to cabotage are summarised in table 3. All regulations limiting cabotage produce a range of negative effects for smaller companies and for companies from peripheral countries, mainly because of the distance factor. The need to return to the base of operation is more damaging for companies from peripheral countries than from core countries. This is the result of the current rather low level of prices per load offered on transport markets not allowing for economic efficiency of a single load run.

Table 3. Expected effects of the new regulations in regard to cabotage

\begin{tabular}{|c|c|c|c|c|c|c|c|c|c|c|c|c|c|}
\hline \multirow[b]{2}{*}{ Company type/origin } & \multicolumn{13}{|c|}{ Area of impact } \\
\hline & 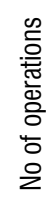 & 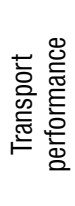 & 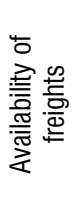 & 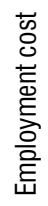 & 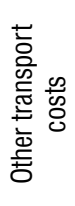 & 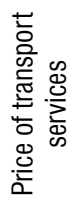 & 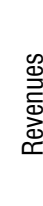 & $\begin{array}{l}\frac{\mathscr{O}}{0} \\
\frac{0}{\bar{O}} \\
\frac{1}{10} \\
\frac{0}{0} \\
0 \\
0\end{array}$ & 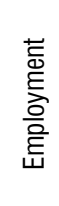 & 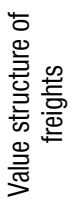 & 点 & 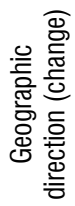 & 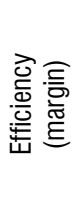 \\
\hline Large-core & 1 & 1 & 2 & 0 & 0 & 0 & 1 & 0 & 0 & 2 & 2 & 0 & 1 \\
\hline Large-peripheral & 0 & 0 & 1 & 0 & -2 & 0 & -1 & 0 & -1 & 1 & -1 & 0 & 1 \\
\hline Small-core & -1 & -1 & 0 & 0 & 0 & -1 & 0 & -1 & 0 & 0 & 1 & 0 & -1 \\
\hline Small - peripheral & -2 & -2 & -2 & 1 & -2 & -2 & -2 & -2 & -2 & -2 & -2 & 0 & -2 \\
\hline
\end{tabular}

Source: the authors' own material.

The necessity to return to the operations base without sufficient time to look for return cargo will result in increased inefficiency and a high number of returns without a load. Cabotage operations were often used by transport companies as operations "in waiting", whereas the market for a cargo for a return trip was being searched. Since the number of available cargo loads remains steady and the market is very competitive, the reduction of the timespan for 
organising a return cargo load is a significant limiting factor. In regard to employment costs, in the short run for peripheral companies the reduction of unit employment costs might be expected due to the reduced need to pay compensation for foreign operations because drivers will be returning home more frequently. This will not impact core countries' companies because they will intercept a big share of the internal core EU countries market, the loads which are currently carried by external transport companies. In a long run, however, those costs might also increase for companies from peripheral countries - those which would like to maintain a strong presence on cabotage markets will introduce driver rotation systems with drivers being transported by bus. This is a solution available to large companies only. This will also be a measure which will impact negatively operational costs other than employment. In general, the increase in the number of compulsory return trips will result in higher fuel costs. This again will be visible predominantly in the case of peripheral countries-based companies because they operate on longer distances. In regard to revenue and prices, it is not possible for hauliers to defend revenue levels through price increases in a short term because the market is very competitive and there exists overproduction of transport services. Thus, in a short term there is no room for price increases. The long-term result will be the elimination of small foreign based companies from national cabotage markets, but given very low entry barriers there is no room for price changes, any void will be rather filled by growing large companies.

The revenues of peripheral countries' companies will be reduced, while the market share will be intercepted by home based - core countries companies. Only large companies from peripheral countries will remain in core countries cabotage markets. Since all the EU national road transport markets are going to be regulated in the same way, there is no possibility for geographical reorientation of main transport activities. Besides, only German, French, and Benelux markets offer cabotage opportunities on the scale required to specialize in one market. Internal markets of CEE, for instance, are not characterized with an excessive number of loads, thus, the negative impacts will predominantly affect companies which operate from outside of the core EU markets. Reorienting services to non-EU markets (e.g. Russia) is not an option due to the security and market access reasons. In regard to employment effects, in a short run companies might try to increase employment in order to meet demands of enforced driver rotation but in the long run, because the majority of small companies even now operates on a very small profit margin, it is likely that they will not be able to maintain higher employment levels. The net result will be a wave of bankruptcies, especially among small transport companies from EU peripheral countries.

Another item on the regulatory agenda is the company domicile. The expected effects of the regulation in regard to the new definition of company residence are summarised in table 4 .

The regulation of residence aims at elimination of "letterbox" companies from the market. Because a majority of those companies are subsidiaries of large transport companies from core countries, set up in peripheral countries in order to take advantage of lower costs and taxation, this regulation will have a positive effect on the peripheral countries-based companies. The effect will be damaging for large companies from core countries, increasing their 
employment costs and leading to a reduction of operations and forcing them to operate on less favourable profit margins. The effects will be also positive for small companies from core countries due to decreased competition on their respective internal markets. Nevertheless, the number of letterbox companies is rather small, thus, the effects will not be noticeable in any significant way.

Table 4. Expected effects of the new regulations in regard to the company domicile

\begin{tabular}{|c|c|c|c|c|c|c|c|c|c|c|c|c|c|}
\hline \multirow[b]{2}{*}{ Company type/origin } & \multicolumn{13}{|c|}{ Area of impact } \\
\hline & 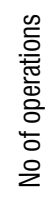 & 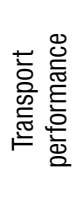 & 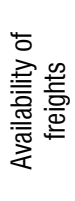 & 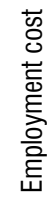 & 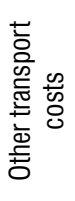 & 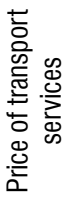 & 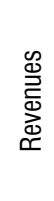 & 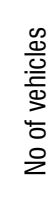 & 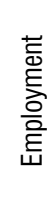 & 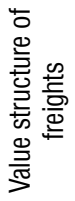 & $\begin{array}{l}\text { 号 } \\
\text { 亮 } \\
\text { E⿱ }\end{array}$ & 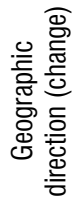 & 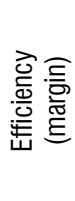 \\
\hline Large-core & -1 & -1 & -1 & -1 & -1 & 0 & -1 & -1 & -1 & 0 & 0 & -1 & -1 \\
\hline Large-peripheral & 0 & 0 & 0 & 0 & 0 & 0 & 0 & 0 & 0 & 0 & 0 & 0 & 0 \\
\hline Small-core & 1 & 0 & 0 & 0 & 0 & 0 & 0 & 0 & 0 & 0 & 0 & 0 & 0 \\
\hline Small - peripheral & 0 & 0 & 0 & 0 & 0 & 0 & 0 & 0 & 0 & 0 & 0 & 0 & 0 \\
\hline
\end{tabular}

Source: the authors' own material.

The "Mobility package" expected effects in regard to yet another field of regulation -redefinition of rest and work time are summarised in table 5.

Table 5. Expected effects of the new regulations in regard to rest and work time

\begin{tabular}{|c|c|c|c|c|c|c|c|c|c|c|c|c|c|}
\hline \multirow[b]{2}{*}{ Company type/origin } & \multicolumn{13}{|c|}{ Area of impact } \\
\hline & 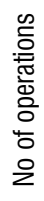 & 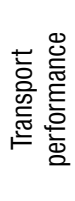 & 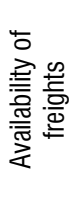 & 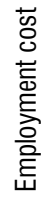 & 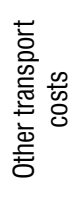 & 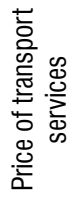 & 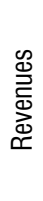 & 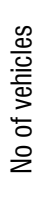 & 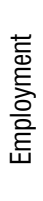 & 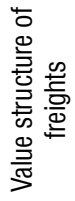 & 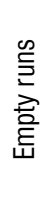 & 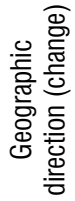 & 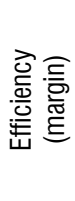 \\
\hline Large-core & 0 & 1 & 0 & 0 & 0 & 0 & 0 & 0 & 0 & 0 & 0 & 0 & 0 \\
\hline Large-peripheral & 0 & 1 & 0 & 0 & 0 & 0 & 0 & 0 & 0 & 0 & 0 & 0 & 0 \\
\hline Small-core & 0 & 1 & 0 & 0 & 0 & 0 & 0 & 0 & 0 & 0 & 0 & 0 & 0 \\
\hline Small - peripheral & 0 & 1 & 0 & 0 & 0 & 0 & 0 & 0 & 0 & 0 & 0 & 0 & 0 \\
\hline
\end{tabular}

Source: the authors' own material

The redefinition of work and rest time conditions, which will introduce a more elastic interpretation of the rules allowing for more short breaks instead of one long break, as well as allowance for the extension of maximum work time in order to reach the final destination will eliminate some of the more absurd behaviours from the road transport. However, its impact on efficiency measures within transport companies is marginal. The negative effects might be registered on the part of small companies if regulation enforcement is accompanied by additional bureaucratic demands. If work and rest time are more regulated, then there will 
be some increase in operational costs due to increased reporting demands. From the large companies' point of view, the proposals look good but again it will only allow eliminating some inefficient actions without a major impact on overall transport performance. The rest and work time regulations will have the same impact on both core and peripheral as well as small and large transport enterprises.

The newly proposed regulations aimed at the elimination of a driver's rest in the vehicle cabin are going to impact the performance of transport enterprises as indicated in table 6 .

Table 6 Expected effects of the new regulations in regard to rest in the vehicle

\begin{tabular}{|c|c|c|c|c|c|c|c|c|c|c|c|c|c|}
\hline \multirow[b]{2}{*}{ Company type/origin } & \multicolumn{13}{|c|}{ Area of impact } \\
\hline & 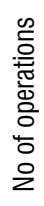 & 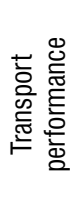 & 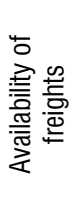 & 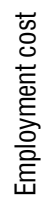 & 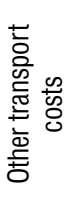 & 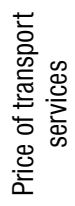 & 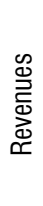 & 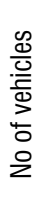 & $\begin{array}{l}\text { 등 } \\
\text { 응 } \\
\text { हैㅡㄹ }\end{array}$ & 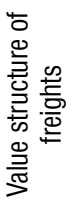 & 竞 & 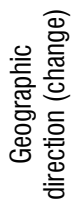 & 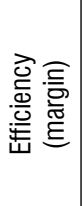 \\
\hline Large-core & 0 & 0 & 0 & -1 & -1 & -1 & -1 & 0 & 0 & 0 & -1 & -1 & -1 \\
\hline Large-peripheral & 0 & 0 & 0 & -1 & -1 & -1 & -1 & 0 & 0 & 0 & -1 & -1 & -1 \\
\hline Small-core & 0 & 0 & 0 & -1 & -1 & -1 & -1 & 0 & 0 & 0 & -1 & -1 & -2 \\
\hline Small - peripheral & 0 & 0 & 0 & -1 & -1 & -1 & -1 & 0 & 0 & 0 & -1 & -1 & -2 \\
\hline
\end{tabular}

Source: the authors' own material

The rest in the cabin regulation is neutral to the number of operations criteria and cargo availability, however, it impacts company efficiency and costs. For long range transport this will have a limited negative impact on the cost of salaries. Companies already pay accommodation equivalents to their drivers. Many drivers prefer to spend the night in the cabin of the truck because modern trucks offer sufficient facilities, but also because they treat the cash equivalent as additional source of income. This regulation will impact all drivers. However, large companies are more likely to arrange with hotels and motels for their employees. This rule will be also very difficult to enforce due to a lack of sufficient roadside infrastructure. In addition, there is an increased risk to the cargo and truck during the driver's absence and possibly to the driver's safety on the transfer from the parking lot to the hotel. There will be an increase in cost due to the need to leave the truck on the protected parking lot. Additional costs will be associated with any paperwork required in order to document the driver's resting time outside the truck cabin. In regard to the composition of vehicle fleets, the change will be rather slow and the difference in truck price minimal. The additional equipment for sleeping facilities will not be needed in trucks but its overall impact on the truck purchase cost is minimal. Forbidding rest in the vehicle will have a minimal or no impact on value structure of loads, and employment, but it might have, in a long run, a significant impact on overall costs and transport prices. Given the lack of sufficient infrastructure, companies will be forced to choose longer routes where infrastructure exists. Those suboptimal choices will be reinforced by fear for cargo safety during the driver's absence and the related rise in insurance 
premiums. The profit margin ratio might decrease since some of the loads will not be accepted for operational reasons.

The final "Mobility package" regulation deals with posting of drivers. Expected effects in regard to posting rules are probably the most taxing on the companies and most controversial. They are summarised in table 7.

Table 7. Expected effects of new regulations in regard to posting rules

\begin{tabular}{|c|c|c|c|c|c|c|c|c|c|c|c|c|c|}
\hline \multirow[b]{2}{*}{ Company type/origin } & \multicolumn{13}{|c|}{ Area of impact } \\
\hline & 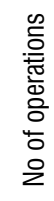 & 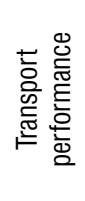 & 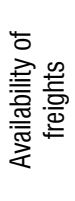 & 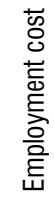 & 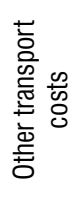 & 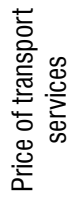 & 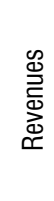 & 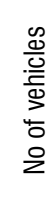 & 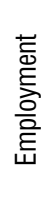 & 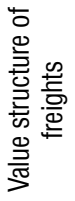 & 总 & 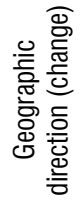 & 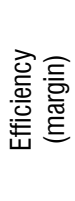 \\
\hline Large-core & -1 & -1 & 0 & -1 & -1 & 1 & 1 & 0 & 0 & 2 & 2 & 0 & 0 \\
\hline Large-peripheral & -1 & -2 & -1 & -2 & -1 & 1 & 1 & 0 & 0 & 1 & 0 & -1 & -1 \\
\hline Small-core & -1 & -1 & 0 & -1 & -1 & -2 & -2 & -1 & 0 & 0 & 1 & 0 & 0 \\
\hline Small - peripheral & -2 & -2 & -1 & -2 & -1 & -2 & -2 & -2 & 0 & -2 & -2 & -2 & -2 \\
\hline
\end{tabular}

Source: the authors' own material

Posting rules applicability to foreign drivers and companies is probably the most challenging of the new regulations. While the general average level of minimal wage in core EU countries remains higher than in peripheral countries, the transport sector employees in peripheral countries earn more than average salaries in their respective places of living. The wage of the international transport driver is better than the average wage universally in all the EU peripheral countries. However, the impact of this regulation might be very damaging to peripheral countries' companies depending on the method adopted in order to calculate the minimal wage. The overall compensation to the driver is built of many additional items except the basic salary. If only the basic salary is calculated towards total, then EU peripheral countries' companies will experience a rapid increase in wage costs. If all other components are also included, then the increase will be more moderate. The problem for transport companies from peripheral countries might be reinforced by additional administrative costs. How to document the wage level? What documents need to be ready? Should they be translated into other languages? If the answer to all those questions is positive, then those additional operational costs will be very significant. Moreover, the use of posting rules will force companies to reorient their transport geographic direction. Drivers will not be willing to accept routes with lower minimal wage and some regions will experience a lack of sufficient supply of transport services. Profit margin efficiency will decline as a result, and there is a high risk that at least for some transport companies profit margins might become negative. Due to the still strong competition in the sector, prices will be stable and revenues will not increase in the short run. However, in the long run, it is almost certain that this regulation will lead to the bankruptcy of small transport companies. Since this might take a massive scale, in the long run price increases are to be expected. 
The impacts are very unevenly distributed between core and peripheral companies. The effects will be more damaging to peripheral companies with currently generally lower wage levels. They will have to adjust, and given the economic surroundings in which they operate, the increase in operational costs might be too high to remain in the market. It has to be mentioned that low labour costs are one of the competitive factors and peripheral countries experience this advantage, which allows them to compensate for advantages experienced by large companies like better access to cheaper capital or core countries companies' advantage in technical and organisational know-how. Adaptive capacity of small companies to the rapid increase in employment and administrative costs is limited. Large companies are able to set up additional administrative units to deal with additional bureaucratic demands and unit costs for them might be acceptable. Small companies employing less than 10 workers would need to hire additional personnel and the cost of this personnel cannot be covered by the revenue from the shrinking number of transport operations. In the short run, the average prices will remain at the same level because companies will continue to use price competition, but with many small companies going out of business it is expected that in the long run prices in the road transport market will increase.

\section{Summary}

The analysis of the impact that the newly proposed EU Commission's road haulage regulations might have on the transport market points to the conclusion that overall those regulations will reduce competition in the sector and will have an unequal impact on small vs large transport enterprises as well as on core vs peripheral based ones. First, the qualitative assessment results show that the most severe consequences of the introduction of the "Mobility package" concern micro- and small enterprises in the road sector. Second, it could be stated that not all the regulatory changes will produce similar effects. The negative effects for enterprises will be to the greatest extent generated by the regulatory changes related to the posting rules and secondarily, to the limiting of cabotage and imposing a ban on regular weekly rest periods in the cabin of the vehicle. It is not possible to quantify the effects in absolute values on the basis of the conducted evaluation, nonetheless, it is possible to estimate the scale of the impact. The results clearly show a significantly greater impact on small enterprises. The impacts are also differentiated by the area of transport activity. While the number of operations or price change are sensitive to change only in the long run, several other company characteristics are immediately responsive, like for instance change in employment and operational costs. Other indicators might change only in reaction to the increased costs - e.g. a possible reduction in the vehicle fleet size will be induced by cost increases which cannot be covered by revenue increases. Due to the very competitive nature of the road transport market and overproduction of transport services, the expected result will be a higher number of bankruptcies among small enterprises and primarily among those from EU peripheral countries. 
The revival of core countries' transport sector will be, however, limited to rather large transport companies instead of the small ones. Revenues will be most impacted by the reduction of transport operations. But this might be as well an after effect of companies defaulting due to too high operational costs. Additionally, revenues seem to be also responsive to the ban on regular weekly rest periods in the cabin and the extension of regulations on posted workers. In the area of pricing the effect will be delayed. In the short run companies will try to maintain their competitive edge by not increasing prices, but with more and more small enterprises going out of business a general increase in prices has to be eventually expected. Wages and operational costs are the main drivers of negative effects in other analysed fields. The new posting rules, enforcement of the ban on rest in the vehicle and cabotage restrictions all add to the higher costs. Changes in both employment and fleet size are also after-effects of what happens to the revenue-cost relation. Since most small transport enterprises already operate on very small profit margins, any worsening of this indicator eliminates them from the transport business. The presented results of qualitative analysis of the new regulations should be augmented by quantitative measures. Those could be, however, only applied when the final and precise shape of the proposal is known. Yet this analysis yields the prediction as to the change and scale of impacts. It is clear that the proposal will have differentiated effect for small and large transport companies and will certainly affect the internal competitiveness of the transport market. They are much less damaging to core countries-based enterprises than to the hauliers from peripheral member states.

\section{References}

\section{Legal documents}

1. Proposal for a Regulation of the European Parliament and of the Council amending Regulation (EC) No 1071/2009 and Regulation (EC) No 1072/2009 with a view to adapting them to developments in the sector, Brussels, $\operatorname{COM(2017)} 281$ final.

2. Proposal for a Directive of the European Parliament and of the Council amending Directive 2006/22/EC as regards enforcement requirements and laying down specific rules with respect to Directive 96/71/EC and Directive 2014/67/EU for posting drivers in the road transport sector, Brussels, COM/2017/0278 final.

3. Proposal for a Directive of the European Parliament and of the Council amending Directive 2006/1/EC on the use of vehicles hired without drivers for the carriage of goods by road, Brussels, COM/2017/0282 final

4. Proposal for a Regulation of the European Parliament and of the Council amending Regulation (EC) No 561/2006 as regards on minimum requirements on maximum daily and weekly driving times, minimum breaks and daily and weekly rest periods and Regulation (EU) 165/2014 as regards positioning by means of tachographs, Brussels, COM/2017/0277. 


\section{Compact publications}

1. Alises A., Vassallo J.M., 2016. The Impact of the Structure of the Economy on the Evolution of Road Freight Transport: A Macro Analysis from an Input-output Approach. Transportation Research Procedia, Volume 14, pp. 2870-2879.

2. Alises A., Vassallo J.M., Guzman A.F., 2014. Road freight transport decoupling: A comparative analysis between the United Kingdom and Spain. Transport Policy, Volume 32, pp.186-193.

3. Patorska J., Lauresh K., 2015. Dokad zmierza jednolity rynek europejski? Wplyw ustawy MiLoG na branżę transportu drogowego w Polsce. Warszawa: Deloitte.

4. Bąk M., Borkowski P., Czuba T., Koźlak A., Zamojska A., 2017. Wpływ rewizji przepisów UE $w$ zakresie międzynarodowego transportu drogowego na przedsiębiorstwa transportowe w Polsce. Warszawa: Ministerstwo Infrastruktury i Budownictwa.

5. Paprocki W., 2015. EU Transport Policy Failure: The Case of Germany's Mindestlohngesetz. In: M. Bąk (Ed.) Transport Development Challenges in the Twenty-First Century. Proceedings of the 2015 TranSopot Conference, Springer.

6. Raczkowski K., Schneider F., Laroche F., 2017. The Impact of Regulation of the Road Transport Sector on Entrepreneurship and Economic Growth in the European Union., Warsaw, Linz, Lyon: Motor Transport Institute.

7. Steer D.G., Frisoni R., Dionori F., Vollath C., Tyszka K., Casullo L., Routaboul C., Jarzemskis A., Tanczos K., 2013. Development and implementation of EU road cabotage. Brussels: European Parliament.

8. Lafontaine F., Malaguzzi V.L., 2009. The deregulation of international trucking in the European Union: form and effect. Journal of Regulatory Economics, Volume 35, Issue 1, pp. 19-44.

9. Ellison R.A., 1985. The impact of transportation deregulation in the United States on Canadian-U.S. distribution channels. Journal of the Academy of Marketing Science, Volume 13, Issue 3, pp. 134-145.

10. Hilal N., 2008. Unintended effects of deregulation in the European Union: The case of road freight transport. Sociologie du Travail, Volume 50, Supplement 1, pp. e19-e29.

11. Krugman P., Fujita M., Venables A., 1999. The spatial economy - cities, regions and international trade. Cambridge: The MIT Press.

\section{Internet based}

1. Eurostat, 2018. Modal split of freight transport, t2020_rk320 dataset from Eurostat database, http://ec.europa.eu/eurostat

2. Eurostat, 2018a. Road freight transport by journey characteristics, http://ec.europa.eu/eurostat/ statistics-explained/index.php/Road_freight_transport_by_journey_characteristics

3. FTA, 2016. Proposed new European road transport rules raise concerns at FTA, http://www.fta. co.uk/media_and_campaigns/press_releases/2016/20170601-Proposed-new-european-roadtransport-rules-raise-concerns-at-fta.html

4. Lakshmanan T.R., Anderson W.P., 2002. Transport infrastructure, freight service sector and economic growth. A White Paper for the U.S. Department of Transportation, Federal Highway Administration, http://www.ncgia.ucsb.edu/stella/meetings/20020115/Lakshmanan.pdf 
5. IRF, 2007. The Socio-Economic Benefits of Roads in Europe, http://www.erscharter.eu/sites/ default/files/16_the_socio_economic_benefits_of_roads_in_europe_EN.pdf

6. EC, 2015. An overview of the EU road transport market in 2015. European Commission, DG for Mobility and Transport, May 2017, https://ec.europa.eu/transport/sites/transport/files/ mobility-package-overview-of-the-eu-road-transport-market-in-2015.pdf

\section{Acknowledgment}

The following experts were consulted in order to assess the impact on road transport during 22.11.2017 public hearing on the "Mobility package" - market/social aspects and road charges: Gerard Schipper - Euro Control Route, Florence Berthelot - FNTR, Ferenc Lajkó - Waberer’s International, Pedro Polónio - ANTRAM, Jan Villadsen - 3F Transport. 
